\title{
IMPROVING STUDENTS' ACHIEVEMENT IN WRITING HORTATORY EXPOSITION TEXTS THROUGH DICTOGLOSS TECHNIQUE
}

\author{
*Nova Susanti \\ **Lidiman S.M. Sinaga
}

\begin{abstract}
This research attempts to improve students' achievement in writing hortatory exposition text by using Dictogloss Technique. The result showed the improvement of students' achievement in writing hortatory exposition text. It was found that the mean of the students' scores in every test was improved. In the first test, the mean was 38.7 and there was $2.3 \%$ of the students who got up 75 points (Minimum Completeness Criteria), in the second test, it was 65.1 and $19.04 \%$ of the students who got up 75 points, and in the last one, the mean was 79.4 and there was $73.8 \%$ of the students who got up 75 points. The students felt enthusiastic, enjoyable, and active in teaching learning process through Dictogloss Technique. The result of the research showed the progress of achievement scores, it can be concluded that Dictogloss Technique gives contribution to improve students' achievement in writing hortatory exposition text.
\end{abstract}

Keywords: Achievement, Writing, Hortatory Exposition Text, Dictogloss Technique

* A graduate of English Language and Literature Department of UNIMED

** A lecturer of English Language and Literature Department of UNIMED 


\section{INTRODUCTION}

\section{Background of the Study}

Communication is an activity of expressing or sharing thoughts, ideas, feelings, and information to other people. There are two ways of communication, namely written and oral. When something is communicated or conveyed in a written form, it is called writing. Writing skills are specific abilities which help students put their thoughts into words in a meaningful form and to mentally interact with the message. (http://www.sil.org).

Nowadays, Students of Senior High School are claimed not only to be able to speak but also to write in English based on the curriculum called Educational Unit-Oriented Curriculum (Kurikulum Tingkat Satuan Pendidikan) which requires students to be able to write various kinds of texts, one of them is hortatory exposition text.

The students must be able to write effectively because they perform their writing skill throughout their life for the academic and occupational purposes such as composing simple stories, writing social letters, papers, theses, and so forth. Walsh (2010:1) in http://www.emergingedtech.com says that writing is used extensively in higher education which leads to a future career. Because of that, writing is an important skill to be learned.

In fact, when doing an observation in SMA Swasta Dharma Pancasila Medan, the writer found that learning writing was still in problem. It was proved by the students' achievement in writing that was still low. Based on the test given by the writer, there was only one student from 42 students ( $2.3 \%$ of the students) who got score up to the Minimum Completeness Criteria (MCC) of English subject in that school that is 75 . Many students still got scores under the standard. Most of the students had difficulty in writing. They did not know how to build sentences that are grammatically correct, had no ideas to express, and lack of vocabulary, based on the data she got after interviewing the teacher and the students. The writer found that the teacher taught her students only about tenses by asking the students to memorize all the pattern of the tenses without giving opportunity for the students to practice their writing skill. It is concluded that students' low achievement in writing is caused by inappropriate teaching technique used by the teacher. 
Therefore, based on the explanation above, it is necessary for a teacher to do an innovation in teaching to improve students' achievement in writing. One of the ways is by applying a dictogloss technique.

Dictogloss technique is an integrated-skills technique for language learning in which students work together to create a reconstructed version of a text read to them. The writer would like to apply dictogloss technique because this technique provides environment for students to practice their writing skill and even in the other language skills (listening, reading, and speaking). Dictogloss technique helps students to create ideas which make students easier to write and teaches students about vocabulary and grammar in context, which makes grammar learning more purposeful and meaningful. Because of that, students will be motivated and interested in learning writing hortatory exposition text by using dictogloss technqiue

It is expected that students' achievement in writing will be improved if the students are taught by using Dictogloss Technique, especially in writing hortatory exposition text that asks students to think critically.

\section{Research Question}

The research problem is formulated as follows: Is students' achievement in writing hortatory exposition text significantly improved if the students are taught by using Dictogloss Technique?

\section{The Scope of the Study}

This study is focused on the application of Dictogloss Technique in teaching writing hortatory exposition text to the students of the second year of SMA Swasta Dharma Pancasila Medan.

\section{The Objective of the Study}

This study is aimed at finding out the improvement of students' achievement in writing hortatory exposition text by using Dictogloss Technique.

\section{The Significance of the Study}

The findings of this study are expected to be useful for:

1) Teachers who may apply this as one of the alternative techniques in improving the quality of teaching writing, especially teaching writing hortatory exposition texts.

2) Students who want to help themselves improve their writing skill 
3) Those who are interested in this study to get more information about improving students' achievement in writing especially writing hortatory exposition text.

\section{Conceptual Framework}

\section{Students' Achievement}

Hornby (2000:11) defines "achievement" as (1) a thing that somebody has done successfully, especially using his own effort and skill (2) the act or process of achieving something.

Yelon, Weinstein, \& Wiener in http://hmsofyanisnianspd.blogspot state that achievement is an indication of the success by the individual.

Concisely, students' achievement is a thing done successfully by students with their efforts and skills.

\section{Writing}

Writing is a means of communicating ideas and information. Troyka (1987:3) in http://teachingenglishonline states that writing is a way of communicating a message to a reader for a purpose. The purposes of writing are to express oneself, provide information for her readers, persuade the readers to do something as proposed in the writing, and create a literary work. Siahaan (2008:215) expresses writing as a psychological activity of the language user to put information into written form.

\section{Hortatory Exposition Text}

According to Siahaan \& Shinoda (2008: 101), hortatory exposition text is a text functioning to persuade readers that they should do something for the benefit of others.

Generic Structure of Hortatory Exposition Text

Every text has specific structures that differentiate one to others. A hortatory exposition text consists of these following structures (Gerot and Wignell, 1994:209):

a) Thesis

Thesis is the announcement of the issue of concern.

b) Arguments

Arguments contain of the reasons of doing something.

c) Recommendation

Recommendation is the statement of what ought to happen. 


\section{Language Features of Hortatory Exposition Text}

Language features of hortatory exposition text are (Gerot and Wignell, 1994:210):

a) Focus on generic human and non-human participants, except for speaker or writer referring to self

b) Use of:

(1) Mental Processes : to state what writer thinks or feels about issue for example: realize, feel, appreciate

(2) Material Processes : to state what happens for example: is polluting, should be treated

(3) Relational Process : to state what is or should be for example: doesn't seem to have been, is

(4) Use of simple present tense

\section{Dictogloss Technique}

Dictogloss is a classroom dictation activity where learners listen to a passage, note down key words and then work together to create a reconstructed version of the text (Vasiljevic, 2010:1).

Wajnryb (1990:16) describes dictogloss as a task-based procedure designed to help language learning students towards a better understanding of how grammar works on a text basis. It is designed to expose the students' shortcomings or needs. So, teaching can be directed more precisely towards these areas.

In dictogloss technique also, all four language skills are practiced:

(1) Listening (to the teacher during dictation, to peers when discussing the reconstruction of the text)

(2) Speaking (to peers during the reconstruction and presentation)

(3) Reading (notes taken while listening to the teacher, the group's reconstruction, and the original text), and

(4) Writing (writing the reconstruction).

Concisely, dictogloss technique is an integrated-skills technique for language learning in which students work together to create a reconstructed version of a text that is grammatically correct and contains the same information as the original text. 


\section{Dictogloss Pocedure}

There are four stages in Dictogloss Technique (Wajnryb, 1990:17), they are:

1) Preparation

Teacher introduces and leads students into the topic of the text, the language focus and the difficult vocabulary. Teacher selects the topics that are related to students' knowledge or interest. Students are divided into several groups before the dictation begins.

2) Dictation (Reading the text)

In dictogloss technique, students normally listen to dictation twice. At first dictation, teacher dictates the text at normal speed. At first, the students just listen to the text so that they become orientated to the topic. They do not take a note during the first dictation. After the first dictation, students are asked to think what the text is about.

In dictating the text for the second time, they jot down some key words which can help them reconstruct the text.

\section{3) Reconstruction}

After the dictation stages, students work in group to reconstruct the text. In reconstruction stage, students compare notes or discuss what they have heard and attempt to produce a coherent text close in content and organization to the original version. Students need not to use accurately the same words as in the original text, but the meaning should not be different and the text should be grammatically correct.

4) Analysis and Correction

The last is analysis and correction stage. In this stage, students compare their text with other various versions and the original one. Students discuss the content, grammar and language choice made. There are various ways of dealing with this stage. The small group versions can be reproduced on the board or overhead projector; the text can be photocopied and distributed. Ideally, the original text should not be seen by students until after their own versions have been analyzed. Students can be asked to check their reconstruction (self-assessment) or the reconstruction of another group (peer-assessment). 
The procedures of teaching hortatory exposition writing by using dictogloss technique can be seen as the following:

Table 2.1 Teaching and Learning Activities

\begin{tabular}{|c|c|}
\hline Teacher's Activities & Students' Activities \\
\hline $\begin{array}{l}\text { Explaining about hortatory exposition text } \\
\text { (social function, generic structures, and } \\
\text { language features: simple present tense). }\end{array}$ & $\begin{array}{l}\text { Listening and paying attention } \\
\text { teacher's explanation }\end{array}$ \\
\hline $\begin{array}{l}\text { Giving a hortatory exposition text to } \\
\text { students. }\end{array}$ & $\begin{array}{l}\text { Identifying generic structures and } \\
\text { language features of the text given by } \\
\text { the teacher and discussing the content } \\
\text { of the text by translating the text } \\
\text { together. }\end{array}$ \\
\hline Dividing students into pairs & Sitting in group \\
\hline Dictating the text discussed before & ning to the text re \\
\hline Dictating the text $\mathrm{f}$ & $\begin{array}{l}\text { Taking note the main information of } \\
\text { the text }\end{array}$ \\
\hline $\begin{array}{l}\text { Asking students to work in group and } \\
\text { reconstruct the text }\end{array}$ & $\begin{array}{l}\text { - Comparing and combining the note } \\
\text { taken while listening to the text read } \\
\text { with their friends in group. } \\
\text { - Reconstructing the text they have } \\
\text { heard which is grammatically } \\
\text { correct and contains of the same } \\
\text { information as the original version. } \\
\text { - Elaborating the information }\end{array}$ \\
\hline $\begin{array}{l}\text { Asking students to present their work in front } \\
\text { of the class }\end{array}$ & $\begin{array}{l}\text { - Presenting their work } \\
\text { - Giving comment related to their } \\
\text { friend's work which is being } \\
\text { presented (grammar and content of } \\
\text { the text). }\end{array}$ \\
\hline Showing the original text in LCD Projector & $\begin{array}{l}\text { Comparing their text with the original } \\
\text { version: grammar and content of the } \\
\text { text (self-assessment). }\end{array}$ \\
\hline $\begin{array}{l}\text { Asking students to do reflection related to } \\
\text { their work. }\end{array}$ & $\begin{array}{l}\text { Analyzing and telling their strengths } \\
\text { and weaknesses. }\end{array}$ \\
\hline
\end{tabular}




\section{METHODOLOGY}

\section{Research Design}

This study applied action research design. Action research refers to teacherconducted classroom research that seeks to clarify and resolve practical teaching issues and problems (Richard and Farrell, 2005: 182).

Carr and Kemmis (1986:162) in http://www.infed.org define action research as simply a form of self-reflective inquiry undertaken by participants in social situations (teachers) in order to improve the rationality and justice of their own practices. Action research is often used to investigate specific issues or problems associated with classroom or school life. The researcher in this research is concerned with using a systematic process in solving educational problems and making improvements.

Zuber-Skerritt (2001:14) in http://scribdassets.com describes action research as critical in the sense that practitioners not only look for ways to improve their practice within the various constraints of the situation in which they are working, but are also critical change agents of those constraints, and of themselves. It is reflective in that participants analyze and develop concepts and theories about their experiences.

Based on the explanation above, it can be concluded that action research is a research which aims to solve educational problems and improve the educational practice by doing reflection.

Action research takes place in the teacher's own classroom and involves a cycle of activities namely planning, acting, observing and reflecting.

The procedures of action research illustrated as follows:
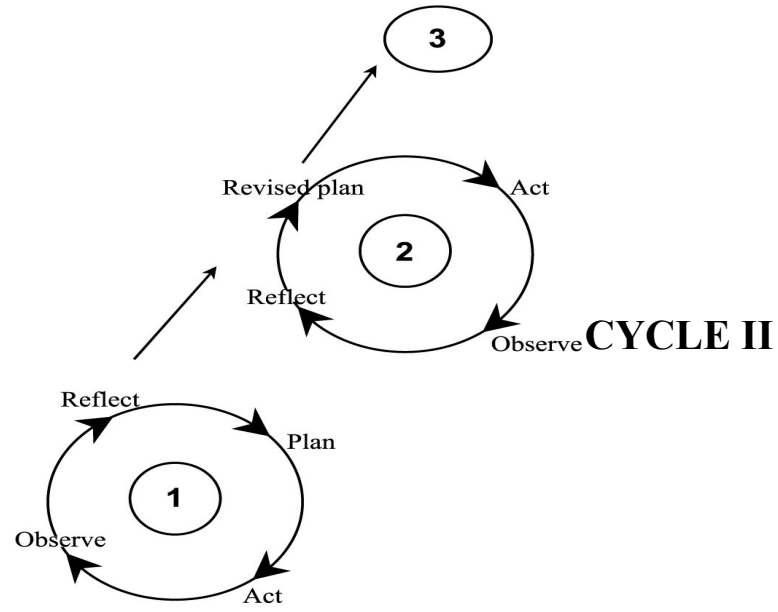


\section{CYCLE I}

\section{Figure 3.1 Simple Action Research Model}

(From zuber-skerritt, 2001:15)

1. Planning

Planning refers to the proposed instructional strategy to be developed in the research to solve instructional problems.

2. Acting

Acting refers to the implementation of new teaching techniques and collecting data. Data collection could include by administering tests, observing students, and conducting surveys and interviews.

3. Observing

In observing, the data indicating success and other instructional problems are recorded, the researcher will take a note of the process of action, the action's effects, environment, and some troubles.

4. Reflecting

Reflecting is the process of analyzing data to determine how far the data collected have shown the success of the strategy in solving the problem. Reflection shows what factors support the success of the strategy or what other problems may occur during the implementation process.

\section{Subject}

The subject of this research was the second year students of SMA Swasta Dharma Pancasila Medan, Jln. Dr. Mansyur No. 71 C, class XI- IPA 1 which consists of 42 students.

\section{Data Collection}

The researcher used written tests, diary notes, observation sheets, and questionnaire sheets as the instruments of data collection. The data in this study were analyzed by using qualitative and quantitative design. The qualitative data were taken from diary 
notes, observation sheets and questionnaire sheets, while quantitative data were taken from students' writing scores.

\section{RESULTS AND DISCUSSION}

The researcher took three writing test scores to show the improvement of students' achievement in their writing assignments from the score of the orientation test given before conducting the research and the writing tests done in the last meeting of each cycle.

The researcher applied the following formula:

$$
\overline{\mathrm{x}}=\frac{\sum \mathrm{x}}{\mathrm{N}}
$$

where: $\quad \overline{\mathrm{x}} \quad=$ the mean of the students' scores

$\sum \mathrm{x}=$ the total scores of the students

$\mathrm{N} \quad=$ the number of the students

The students' scores increased from the first competence test to the last competence test. It can be seen in Table 4.1.

Table 4.1 Students' Writing Scores in Test I, Test II and Test III

\begin{tabular}{|c|c|c|c|c|}
\hline No. & $\begin{array}{c}\text { Students' } \\
\text { Initials }\end{array}$ & $\begin{array}{c}\text { Test I } \\
\text { (orientation test) }\end{array}$ & $\begin{array}{c}\text { Test II } \\
\text { (last meeting of } \\
\text { cycle I) }\end{array}$ & $\begin{array}{c}\text { Test III } \\
\text { (last meeting of } \\
\text { cycle II) }\end{array}$ \\
\hline 1. & AP & 38 & 74 & 75 \\
\hline 2. & ASL & 33 & 63 & 82 \\
\hline 3. & AP & 24 & 35 & 69 \\
\hline 4. & AW & 34 & 76 & 87 \\
\hline 5. & AH & 49 & 69 & 87 \\
\hline 6. & AS & 61 & 63 & 69 \\
\hline 7. & DO & 28 & 60 & 79 \\
\hline 8. & DDK & 48 & 70 & 78 \\
\hline 9. & DC & 22 & 43 & 98 \\
\hline 10. & DS & 32 & 70 & 65 \\
\hline 11. & DD & 43 & 84 & 74 \\
\hline 12. & EEB & 38 & 64 & 71 \\
\hline 13. & HU & 32 & 65 & 74 \\
\hline 14. & HA & 42 & 63 & \\
\hline 15. & HS & 24 & 56 & 92 \\
\hline
\end{tabular}




\begin{tabular}{|c|c|c|c|c|}
\hline 16. & HSH & 47 & 64 & 79 \\
\hline 17. & IN & 64 & 73 & 79 \\
\hline 18. & JA & 30 & 76 & 79 \\
\hline 19. & KI & 69 & 79 & 93 \\
\hline 20. & M & 40 & 53 & 64 \\
\hline 21. & MPA & 19 & 63 & 75 \\
\hline 22. & M & 17 & 48 & 71 \\
\hline 23. & MABS & 36 & 54 & 82 \\
\hline 24. & MFAL & 55 & 57 & 84 \\
\hline 25. & MFP & 11 & 54 & 66 \\
\hline 26. & MFA & 37 & 72 & 76 \\
\hline 27. & MTK & 36 & 77 & 89 \\
\hline 28. & NY & 33 & 75 & 82 \\
\hline 29. & NB & 18 & 42 & 64 \\
\hline 30. & NSS & 47 & 68 & 89 \\
\hline 31. & PM & 56 & 87 & 93 \\
\hline 32. & RZMK & 46 & 72 & 82 \\
\hline 33. & RA & 24 & 45 & 81 \\
\hline 34. & RTY & 18 & 63 & 77 \\
\hline 35. & RA & 40 & 63 & 84 \\
\hline 36. & SR & 62 & 70 & 82 \\
\hline 37. & SN & 85 & 89 & 98 \\
\hline 38. & SA & 50 & 68 & 79 \\
\hline 39. & TPUK & 13 & 63 & 64 \\
\hline 40. & WW & 40 & 63 & 82 \\
\hline 41. & YS & 56 & 69 & 82 \\
\hline 42. & ZAP & 29 & 68 & 79.4 \\
\hline & $\sum X$ & 1626 & 2734 & \\
\hline & $\bar{X}$ & 38.7 & 65.1 & 836 \\
\hline & & & & 69 \\
\hline
\end{tabular}

From the data above, it can be said that the mean of students' writing scores after studying hortatory exposition text through Dictogloss Technique increased from 38.7 to 79.4. Based on the data analysis, it could be concluded that all the students got improvement in their scores even though they got different improvement.

The indicator of successful achievement of students was that they got score up to 75 . The researcher applied the following formula:

$$
\mathrm{P}=\frac{\mathrm{R}}{\mathrm{T}} \times 100 \%
$$


where: $\quad \mathrm{P} \quad=$ the percentage of the number of the students

$\mathrm{R}=$ the number of those who get the scores.

$\mathrm{T}=$ the total number of the students

In Test I, there was 1 student (2.3\%) who got up to 75 point. In Test II, there were 8 students $(19.04 \%)$ who got up to 75 points and in Test III, there were 31 students (73.8\%) who got up to 75 points. The range of the first test $(2.3 \%)$ and the third test (73.8\%) was $71.5 \%$. It had been proved that the applying of Dictogloss Technique in teaching learning activity helped the students improve their achievement in writing hortatory exposition text.

The writer also analyzed the qualitative data to support this research finding. The qualitative data were taken from diary notes, observation sheets and questionnaire sheets to know how dictogloss technique could improve the students' ability in writing.

The diary notes indicated that the situation of teaching and learning process was better from the first to the last meeting. The students were interested, enthusiastic, and active when teaching learning process was running. They paid full attention and did the assignments seriously.

Then, from the observation sheets, there was significant progress that was shown in every meeting, especially in the second cycle, the students were enthusiastic, active and interested in studying. Their attention became better and their mistakes were decreased.

Last, the questionnaire sheets showed that most of the students' understanding about hortatory exposition text became improved by using dictogloss technique. Based on the students' comments written on questionnaire sheets showed that dictogloss technique could create their creativity in writing because they could elaborate the ideas provided by dictogloss technique. The steps on Dictogloss Technique help the students write systematically and make them active. Writing hortatory exposition text by using dictogloss technique was interesting.

Based on the results of quantitative and qualitative data, it was found that the use of dictogloss technique had successfully improved hortatory exposition writing achievement.

\section{CONCLUSION AND SUGGESTIONS}

\section{Conclusion}


After analyzing the data, it was found that the students' writing scores improved from the cycle I until the cycle II. The improvement was shown by the mean of the students' scores from the first test (orientation test) 38.7, the second test (in the last meeting of cycle I) 65.1 and the last test (in the last meeting of cycle II) 79.4. The students' scores continuously improved in each writing test. The percentage of the students who were competent in writing hortatory exposition text was also improved, where in Test I, there was $2.3 \%$, in Test II $21.4 \%$ and in Test III, the percentage was improved to be $71.4 \%$.

From the data, it can be concluded that teaching hortatory exposition writing by using dictogloss technique helps the students to improve their achievement in writing hortatory exposition text.

\section{Suggestions}

This study shows that the application of Dictogloss Technique improves the students' achievement on writing hortatory exposition text. Due to the conclusion above, there are some points suggested as follows:

1) The teachers may apply dictogloss technique as one of the alternatives teaching techniques, especially teaching writing, to stimulate students' interest in writing.

2) The students can improve their writing skill.

3) Readers may use the information in this research as a useful input in teachinglearning process especially for teaching writing.

\section{REFERENCES}

Carr and Kemmis. 1986. Action Research. Available at 
http://www.infed.org/research/b-actres.htm accessed on January $28^{\text {th }}$, 2012.

Gerrot, L. \& Wignell, P. 1994. Making Sense of Functional Grammar.

Cammeray: Antipodean Educational Enterprises.

Hornby, A. S. 2003. Oxford Advanced Learner's Dictionary ( $6^{\text {th }}$ Ed). Great Britain: Oxford University.

Richards, J.C. and Farrell, T. S. C. 2005. Professional Development for Language Teachers Strategies for Teacher Learning. Cambridge : Cambridge University Press.

Siahaan, S. 2008. Issues in Linguistics. Yogyakarta: Graha Ilmu.

Siahaan, S. \& Shinoda, K. 2008. Generic Text Structure. Yogyakarta: Graha Ilmu.

Troyka. 1987. Definition of Writing Ability. Available at http://teachingenglishonline.net/definition-of-writing-ability accessed on January $28^{\text {th }}, 2012$

Vasiljevic, Z. 2010. Dictogloss as an Interactive Method of Teaching Listening Comprehension to L2 Learners. English Language Teaching. Vol. 3 No. 1

Wajnryb, R. 1990. Grammar Dictation. Oxford: Oxford University Press.

Walsh, K. 2010. The Importance of Writing Skills. Available at http://www.emergingedtech.com accessed on December 13 ${ }^{\text {rd }}, 2011$

Yelon, et al. 2009. Definition of Achievement. Available at http://hmsofyan isnianspd.blogspot.com/2009/08/definition-of-achievement.html accessed on January $28^{\text {th }}, 2012$

Zuber, S. 2001. Action Research. Available at http://scribdassets.com accessed on April $12^{\text {th }}, 2012$

http://www.sil.org/lingualinks/literacy/Referencematerials/gglossaryofliteracy terms/WhatAreWritingSkills.htm accessed on December 29 ${ }^{\text {th }}, 2011$

\section{APPENDIX}

The Mean of Students' Scores 
In Test I, the students' total score was 1626 and the number of the students was 42 . The mean was:

$$
\bar{X}=\frac{1626}{42}=38.7
$$

In Test II, the students' total score was 2734 and the number of the students was 42 .

The mean was:

$$
\bar{X}=\frac{2734}{42}=65.1
$$

In Test III, the students' total score was 3336 and the number of the students was

42. The mean was:

$$
\bar{X}=\frac{3336}{42}=79.4
$$

\section{The Number of Competent Students}

The percentage of the improvement of students' hortatory exposition writing achievement in Test I:

$$
P=\frac{1}{42} x 100 \%=2.3 \%
$$

The percentage of the improvement of students' hortatory exposition writing achievement in Test II:

$$
P=\frac{8}{42} \times 100 \%=19.04 \%
$$

The percentage of the improvement of students' hortatory exposition writing achievement in Test III: 


$$
P=\frac{31}{42} x 100 \%=73.80 \%
$$

